Review

\title{
Role of NK Cells in Cancer and Immunotherapy
}

\author{
Paresh Vishwasrao ${ }^{1,2, *}$, Susanta K. Hui ${ }^{1}$, D. Lynne Smith ${ }^{3}$ and Vishal Khairnar ${ }^{4}$ \\ 1 Department of Radiation Oncology, City of Hope Medical Center, 1500 E Duarte Rd, Duarte, CA 91010, USA; \\ shui@coh.org \\ 2 Department of Hematology, Academic Medical Center, University of Amsterdam, Amsterdam Meibergdreef 9, \\ 1105 AZ Amsterdam, The Netherlands \\ 3 Department of Hematology, City of Hope Medical Center, 1500 E Duarte Rd, Duarte, CA 91010, USA; \\ lysmith@coh.org \\ 4 Department of Medical Oncology, Dana-Farber Cancer Institute, Harvard Medical School, \\ Boston, MA 02115, USA; vishals_khairnar@dfci.harvard.edu \\ * Correspondence: pvishwasrao@coh.org; Tel.: +1-201-491-3741
}

check for

updates

Citation: Vishwasrao, P.; Hui, S.K.; Smith, D.L.; Khairnar, V. Role of NK Cells in Cancer and Immunotherapy. Onco 2021, 1, 158-175. https:// doi.org/10.3390/onco1020013

Academic Editor: Fred Saad

Received: 15 October 2021

Accepted: 24 November 2021

Published: 3 December 2021

Publisher's Note: MDPI stays neutral with regard to jurisdictional claims in published maps and institutional affiliations.

Copyright: (C) 2021 by the authors Licensee MDPI, Basel, Switzerland. This article is an open access article distributed under the terms and conditions of the Creative Commons Attribution (CC BY) license (https:// creativecommons.org/licenses/by/ $4.0 /)$.
Simple Summary: Natural killer cells are the first line of defense against tumor surveillance. Currently, efforts are being made to harness the potential of NK cells as tools for immunotherapy. Rapid progress is being made in engineering NK cells for tumor immunotherapy. Chimeric antigen receptor (CAR)-engineered NK (CAR-NK) cells are gaining ground on CAR-T cells because of better safety, cytotoxic function, and high feasibility for "off-the-shelf" manufacturing. In addition, bispecific NK cell engagers (BiKEs) and trispecific NK cell engagers (TriKEs) therapy have proven beneficial in solid tumors. In this review, we will focus on recent progress in the therapeutic competence of NK cell immunotherapy, including CAR-NK and BiKE across several in vivo and in vitro models.

Abstract: Increasing knowledge of cancer immunology has led to the design of therapies using immune cells directly or manipulating their activity, collectively termed immunotherapy. In the field of immuno-oncology, research on adaptive immune T cells has led to the development of CAR-T cells. Innate immune cells such as NK cells can also eliminate oncogenically transformed cells and regulate cells of the immune system. Considering NK cells as a live drug, numerous methods for the isolation and activation of NK cells have been shown to be clinically and therapeutically relevant. In such processes, various cytokines and antibodies present a source of stimulation of NK cells and enhance the efficacy of such treatments. The ex vivo expansion and activation of NK cells, along with genetic modification with CAR, enhance their antitumor activity. Recent preclinical studies have shown an antitumor effect through extracellular vesicles (EVs) derived from NK cells. Work with autologous NK cells has provided insights for clinical applications. In this review, we outline the recent advances of NK-cell-based immunotherapies, summarizing CAR-NK cells, BiKEs, and TriKEs as treatment options against cancer. This review also discusses the challenges of NK cell immunotherapy.

Keywords: natural killer (NK) cells; cancer; immunotherapy; chimeric antigen receptor (CAR)-NK; iPSCs; bispecific T-cell engagers (BiKEs); trispecific NK cell engagers (TriKEs)

\section{Introduction}

Natural killer (NK) cells are the body's first line of defense against infected or transformed cells, as they kill target cells in an antigen-independent manner. Unlike adaptive immune T and B cells, NK cells are innate immune cells that do not undergo somatic rearrangements to produce highly specific receptors that recognize target cells or antigens. Broad systemic tissue distribution of NK cells can carry out different functions. NK cells express both activating and inhibitory receptors, which function to maintain physiological balance. Perturbation of this balance leads to activation of NK cells. NK cells can lyse tumor cells without the need for priming, and this plays an essential role in controlling tumor growth $[1,2]$. All NK cell receptors are germline encoded; thus, they are independent 
of recombination-activating gene (RAG) rearrangement activity for function. NK cells play a pivotal role in immunosurveillance $[3,4]$ and represent an important effector cell type for adoptive cancer cell therapy [5-7]. Human NK cells are identified by the absence of the T-cell receptor (TCR) complex (i.e., cluster of differentiation (CD)3 negative) and the presence of the neural cell adhesion molecule (NCAM; also known as CD56) [8,9]. Fundamentally, NK cells are recognized for eliminating cells that lack expression of major histocompatibility complex (MHC) class I, also known as human leukocyte antigen (HLA). Binding of the MHC class-I ligand to NK cell inhibitory receptors, such as killer cell immunoglobulin-like receptors (KIRs), is a signal of self-recognition, which avoids activation and killing of self/healthy cells. Human NK cells acquire effector functions by an education process termed "licensing", which is mediated by the interaction between KIR with-MHC class-I molecules [10,11]. NK cells are regarded as innate immune cells and surprisingly share important characteristics with the adaptive immune system, in particular CD8 T cells [12,13]. Engagement of the wide array of activating surface receptors that recognize ligands upregulated by cancer cells, such as natural cytotoxicity receptors (NCRs), activates NK cell tumor cytotoxicity and the secretion of antitumor cytokines, such as interferon-gamma (IFN- $\gamma$ ) and tumor necrosis factor-alpha (TNF- $\alpha$ ) [14-16]. In summary, the balance between signals received for inhibitory receptors and activation receptors via foreign and self-antigens is the deciding factor for its effector function.

Cell-based therapies are emerging to supplement traditional chemotherapy and radiotherapy cancer treatments. In cell-based therapy, effector immune cells are isolated from the patient's blood, expanded and activated outside the body (ex vivo), and then adoptively transferred back into the patient as a form of "immunotherapy" [17]. During the past decade, the concept of immune cells eliminating cancer cells has been successfully translated from bench to bedside, which is termed "Cancer Immunotherapy". Notably, harnessing this potential of immune cells with the clinical success of autologous CAR-T cells in patients with leukemia and lymphoma has increased the potential of cancer treatment. Furthermore, methods of applying these concepts to other immune cells for such treatment have been gaining importance.

Efforts to utilize other effector immune cells such as NK cells have been explored [18,19]. A groundbreaking study of donor-mismatched allogeneic NK cells on the outcomes of patients with acute myeloid leukemia (AML) took advantage of the lack of TCR-like receptors on NK cells. This study showed that allogeneic NK cells protected against graft versus host disease (GvHD) [20]. This phenomenon prompted the idea of utilizing NK cells as "live drugs" in "off-the-shelf" immunotherapy products. Although peripheral blood mononuclear cells (PBMCs) contain only 10-12\% of circulating NK cells, there are other sources such as umbilical cord blood (UCB) and induced pluripotent stem cells (iPSCs) that can also contribute and hold a promising way to expand and accumulate a large number of NK cells.

In-depth descriptions of NK-cell-activating and inhibitory markers can be found in the literature [21-23], along with a summary of sources and methods for the isolation, activation, and propagation of allogeneic NK cells, which is readily available $[24,25]$. In this review, we will discuss the strategies and preclinical and clinical efforts made to use these "live drugs" as cancer immunotherapy.

\section{NK-Cell-Based Cancer Immunotherapy}

NK cells are bone-marrow-derived lymphocytes that arise from multipotent CD34+ hematopoietic progenitors [26]. NK cell maturation occurs in bone marrow, as well as in lymphoid organs. They continuously receive signals and cytokines for proliferation and activation throughout their lifespan. After differentiation, human interleukin-15 (IL-15) plays an indispensable role in the homeostatic maintenance of NK cells in the peripheral blood [27]. The in vivo kinetics of human NK cells from a healthy young adult occur in approximately 10-12 days, while the mean proliferation rate or doubling time is roughly 13-16 days (turnover in blood of about two weeks) [28]. Some of the challenges of NK- 
cell-based immunotherapy are in vivo persistence of the NK cells, tumor localization, and homing to the tumor microenvironment. Similar to T cells, genetic manipulation of NK cells could be a solution that enhances their persistence, cytotoxicity, tumor-targeting capacity, and ability to home to disease sites in vivo. Improving the efficacy of NK-cell-based cancer immunotherapy has yielded good preclinical results. Here, we summarize a few of the strategies and efforts to overcome some of the limitations.

\section{Adoptive NK Cell Therapy}

Initial studies on adoptive NK cell therapy focused on antitumor activity through autologous and allogeneic transfer [29]. Efforts were made to enhance and improve the therapy by increasing the efficiency of killing tumor cells. These therapies are largely based on isolation of human NK cells, using CD56 as a cell surface target antigen, utilizing beads from a leukapheresis product, and subsequently infusing these autologous NK cells back into patients [29]. Due to the shorter lifespan of NK cells, systemic administration of cytokines such as interleukin-2 (IL-2) was provided in vivo to stimulate and support the expansion of activated NK cells. In vitro cytokine-activated NK cells have resulted in enhanced cytotoxicity; however, they have shown limited in vivo antitumor activity [30,31]. In clinical settings, autologous NK cells that were ex vivo activated and reinfused in lymphoma patients, followed by administration of systemic IL-2, resulted in a poor outcome [32]. First, the development of severe life-threatening side effects/severe adverse effects (SAEs), such as vascular leak syndrome, as a result of IL-2 therapy was observed. Secondly, IL-2 induced expansion of regulatory T cells, leading to inhibition of NK cell function, and induced NK cell death due to activation [33,34]. Additionally, the inhibition of autologous NK cells by self-HLA molecules resulted in the lack of antitumor effects. To overcome these limitations, new strategies were designed to redirect autologous NK cells to target and kill leukemic blasts. These strategies use anti-KIR antibodies to block inhibitory receptors on the NK cell surface with their cognate HLA class-I ligands.

Although NK cells recognize and kill tumor cells in vitro, the tumor microenvironment (TME) plays an important role in determining their antitumor efficacy in vivo. For example, not all solid tumors are equally well infiltrated by NK cells, as many infiltrated NK cells tend to be dysfunctional [35-37]. The failure of immune surveillance could be partially explained as sustained immunological pressure on tumor cells resulting in the development of tumor escape variants that are invisible to the immune system. Even cytotoxic functions of immune effector cells are compromised in the TME due to tumor-secreted suppressive soluble factors, as well as suppressive immune compartments, such as myeloid-derived suppressor cells (MDSCs), tumor-associated macrophages (TAMs), and regulatory T cells (Tregs) [38]. Treg cells are defined as small T-cell subpopulations within the CD4+ cell subpopulation that have high affinity towards IL-2 receptor alpha (CD25, IL-2R $\alpha)$ and express a nuclear factor forkhead box 3 protein (FoxP3), which need IL-2 cytokines to maintain their function [39]. Experimentally, it was shown that NK cells were suppressed by Tregs in a cell-contact-dependent manner via membrane-bound TGF- $\beta$ that attenuated NK cytotoxicity in vitro [40]. An inverse correlation between NK cell activity and Tregulatory (Treg) cell expansion has been observed in patients with gastrointestinal stromal cancer (GIST) or hepatocellular carcinoma. Some studies indicate that NK cell proliferation, accumulation, and activation can be limited by Tregs through the availability of IL-2 released by CD4+ cells, which leads to inadequate IL-2-activated CD4+ T cells.

\section{Use of Ex Vivo-Activated NK Cells}

A different approach has been taken to facilitate effective NK cell function by priming ex vivo-isolated NK cells (CD56+ selection) with different cytokines to have antitumor activity, followed by expansion and infusion in cancer patients to augment NK cell function and antibody-dependent cell cytotoxicity (ADCC). In contrast to autologous NK cells, which are inhibited by recognition of a self-HLA-I molecule expressed on tumor cells and therefore show reduced antitumor potential, the KIR/HLA-I mismatch in allogeneic 
NK settings has led to more promising outcomes, along with hematopoietic stem cell transplant (HSCT) in hematologic malignancies [41]. Interactions of inhibitory receptors with HLA class-I molecules on autologous cells induce dominant negative signals that override activating inhibitory receptor signaling in cells. These interactions are responsible for preventing cytotoxic activity [41]. Among inhibitory receptors, Ig-like transcript 2 recognizes all HLA class-I molecules on somatic cells by engaging the conserved $\beta 2$ macroglobulin and $\alpha 3$ domain of HLA class-I molecules [42]. Some methods, which employ ex vivo expansion of NK cells, require coculturing on the modified K562 feeder cell line. K562 can act as an excellent targeting cell line due to the downregulated MHC class-I inhibitory receptors. Modified K562 cells have membrane-bound IL-15 and 41BBL, which have proven to help in this expansion, activation, and proliferation, resulting in higher antitumor activity in vitro, as well as in mouse models [43]. Another example, a combination of feeder cell EBV-LCL and cytokine IL-2 supplementation, led to robust NK cell activation. These activated NK cells were found to be expanded by $200-$ to 600 -fold over 21 days [44]. In clinical settings, one of the main questions being answered is the survival time of allogeneic cells after adoptive transfer. Reports indicate several weeks to months of cell survival depending upon the expansion method and the subpopulation transfer [45].

Recently, NK therapy has been modified with the addition of ex vivo cytokines for activation and expansion. As previously mentioned, the well-studied cytokine IL-2 was infused along with NK cell therapy. Other cytokines such as IL-12, IL-15, IL-18, IL-21, and IFN- $\gamma$ have been studied for their relative effects on activation and expansion of NK cells [46,47]. In comparison to other cytokines, IL-15 presented an advantage, as it did not stimulate Tregs as well as in the preclinical model, and it showed some promising results. Although an antitumor effect was observed in in vivo studies, an excessive amount of IL-15 was required to achieve these effects. Imamura et al. showed that the expression of membrane-bound IL-15 (mbIL-15) in human NK cells sustained their growth and increased antitumor activity [47]. In this study, the significance of mbIL-15 was determined by expressing mbIL-15 on the cell surface of NK cells. Compared to non-membrane-bound NK cells, mbIL-15 NK cells showed higher survival in vitro and did not require IL-2. mbIL15-expressing cells essentially retained the immunophenotype of activated NK cells, as well as functional properties of CD107a expression and IFN- $\gamma$ secretion. In mouse studies, expansion of mIL15 NK cells was observed as an autocrine effect in most of the tissues except the brain. This was further enhanced with administration of IL-2 in an immunodeficient mouse model. The potency and antitumor effect of mbL15 NK cells were underscored by enhanced cytotoxicity against leukemia and lymphoma cell lines. In a xenograft model of NOD/scid IL2RGnull (NSG) mice transplanted with Ewing sarcoma cell line (solid tumor), mbL15 NK cells showed superior cytotoxicity against carcinoma with prolonged survival benefit compared to the untreated group. This approach forms the basis for strategies that could improve the antitumor capacity of NK cell infusions, thereby avoiding the need to administer IL-2 dose-limiting.

\section{NK Cells and CARs}

The improvement of effector cell cytotoxicity or its ability to destroy cancer cells can be specifically redirected by the recombinant chimeric antigen receptor (CAR), which consists of a single-chain variable fragment ( $\mathrm{scFv}$; ectodomain) linked to intracellular signaling domains (endodomain). The scFv binds to a defined target antigen on tumors or transformed cells and triggers effector cell activation upon target engagement [48,49]. In general, CAR affinity and functionality are subject to the interplay between the antigenbinding $\mathrm{scFv}$ antibody, hinge region, transmembrane region, and endodomain. This also means that each new CAR construct should be experimentally tested for a specific target antigen and application [50]. Currently, many cancer target antigens are under clinical investigation, including CD19, CD20, CD30, CD138, epidermal growth factor receptor variant II (EGFRvII), disialoganglioside (GD2), human epidermal growth factor-2 
(HER-2), Wilms' tumor (WT1), prostate-specific membrane antigen (PSMA), and New York esophageal squamous cell carcinoma 1 (NY-ESO1) in multiple cancer types. Additional target antigens are currently in preclinical development [51].

With the success of CAR-T cells in hematological malignancies, the field is presently exploring NK cells for antitumor activity. Previous research on NK cell biology has found various sources of NK cells, where each source is subjected to engineering with different CAR constructs. Although all of these sources have their own advantages, each of these needs to be investigated for their safety and efficacy before they can be utilized in clinical applications. Here we provide sources and methods for isolation of NK cells in Figure 1. Please find below the list of targeted antigens and their respective details of study conducted in Table 1 and list of clinical trials in Table 2.

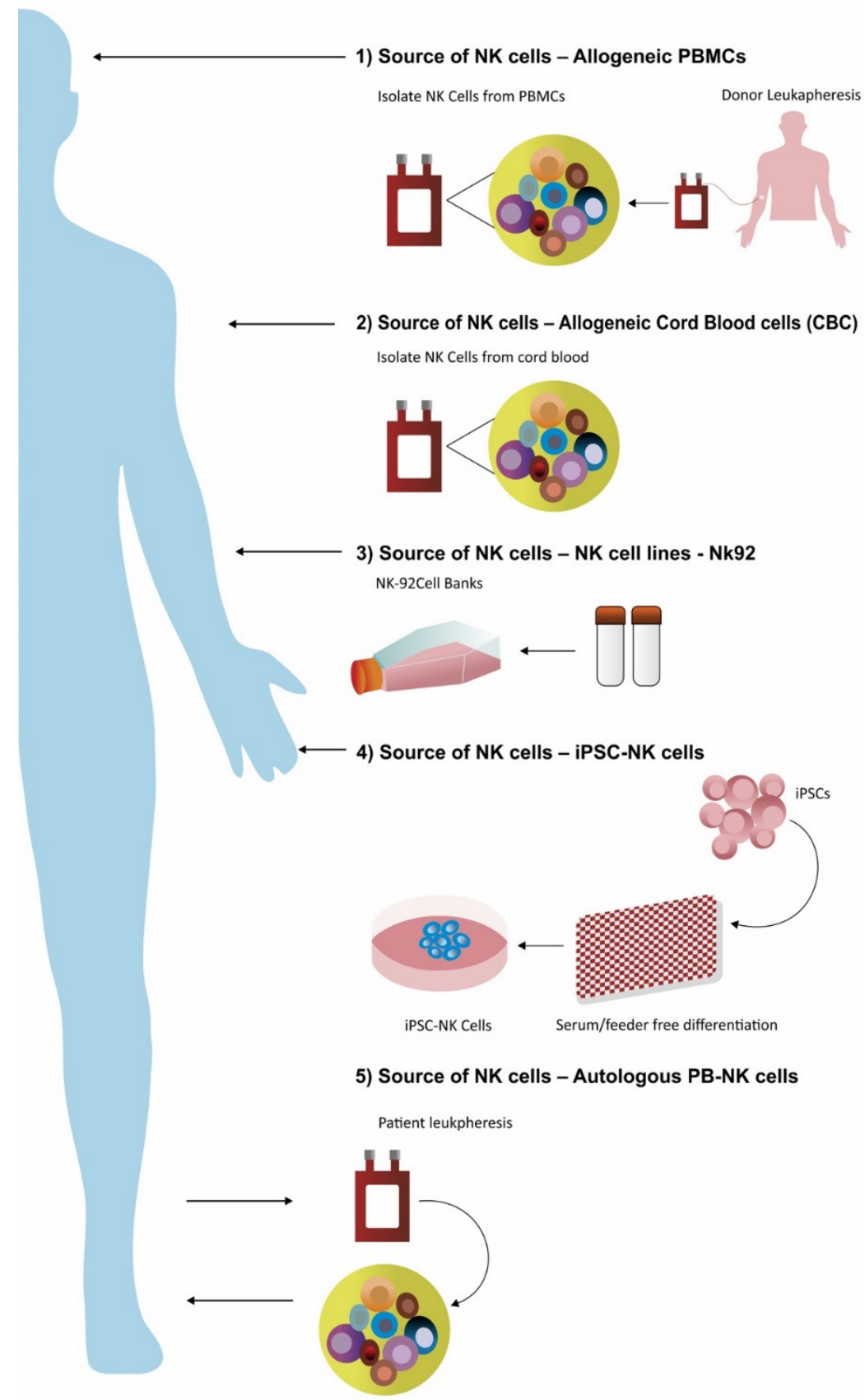

Figure 1. Sources and methods for isolation of NK cells. (1). Allogeneic PBMCs: primary peripheral blood (PB)-NK cells. A way to obtain PBMCs from healthy donors is through leukapheresis. PBMCs are depleted for $\mathrm{T}$ cells (CD3+ with CD3 immunomagnetic particles), and NK cells are further enriched 
with CD56+ cell selection (CD56 immunomagnetic particles). T-cell-depleted PBMCs or enriched NK cells are infused or activated with a 12-16 h culture with cytokines (IL-2 or a mixture of IL-12, IL-15, and IL-18), which have been used in clinical studies [45,52]. After enrichment of NK cells, they can be propagated ex vivo for 10-15-days for coculture with stimulatory cells, such as the programed K562 cell line. The modified K562 expresses a membrane-bound IL-15 (mbIL-15) and 4-1BBL. This membrane-bound cell line is necessarily irradiated before coculturing with PBMCs to avoid its own expansion [53,54]. (2). NK cell line (NK92): NK-92 cells can easily be genetically manipulated to recognize specific tumor antigens or to augment monoclonal antibody activity through ADCC. NK-92 is also the only cell line product that has been infused into patients with clinical benefits and minimal side effects [55]. (3). Allogeneic cord blood cells (CBCs): Cord blood NK cells (CB-NK) have been used in preclinical research. Unlike PBMCs, the population of active CD16 + NK cells is somewhat low, but they can be enriched, activated, and propagated, similar to peripheral blood NK cells. CB is also an abundant source of CD34+ hematopoietic progenitors, which can be harvested from umbilical cord blood using CD34 immunomagnetic particles. Growth factors and cytokines could promote their proliferation and differentiation to NK cells, respectively [56]. (4). iPSC-derived NK cells: This source has an unlimited proliferation potential, whereas iPSC-NK cells are first promoted through hematopoietic progenitor differentiation factors and then NK cell differentiation with additional lineage factors, followed by propagation with a stimulatory cell line expressing mbIL-21 [57]. iPSCNK cells can be produced from a standardized cell population to provide a homogeneous NK cell population that can be grown up to scale for clinical use [58,59]. (5). Autologous NK cells: peripheral blood can be used as a source of NK cells (PB-NK). NK in peripherl blood constitutes of 5-10\% of total PBMCs. There are two major subpopulation of NK cells in PBMCs and can be distinguished as CD56bright and CD56dim. Most of the NK cells from blood are mature phenotype expressing CD16. PB-NK cells is a good source for creating effective CAR-NK cells [60].

Table 1. CAR-NK constructs for clinical trials.

\begin{tabular}{|c|c|c|c|c|c|c|}
\hline Year & Researcher & Target & CAR Construct & Method & Tumor Targets & Ref \\
\hline 2002 & Uherek et al. & ErbB2 (HER-2) & $\mathrm{mCD} 8 \alpha$ hinge/CD3 $\zeta$ & Amphotropicvirus & $\begin{array}{c}\text { Tumors of } \\
\text { epithelial origin }\end{array}$ & [61] \\
\hline 2008 & Müller et al. & CD20 & $\mathrm{mCD} 8 \alpha$ hinge/CD3 $\zeta$ & Amphotropicvirus & $\begin{array}{l}\text { Lymphoma and } \\
\text { leukemia }\end{array}$ & {$[62]$} \\
\hline 2009 & Boissel et al. & CD19 & $\mathrm{CD} 8 \alpha \mathrm{TM} / \mathrm{CD} 3 \zeta$ & $\begin{array}{l}\text { mRNA transfection } \\
(50 \%)\end{array}$ & $\begin{array}{c}\text { Chronic } \\
\text { lymphocytes } \\
\text { Leukemia }\end{array}$ & {$[63]$} \\
\hline 2012 & Sahm et al. & EpCAM & $\begin{array}{c}\text { CD8 } \alpha \text { hinge/CD28/ } \\
\text { CD3 } \zeta\end{array}$ & $\begin{array}{c}\text { Lentivirus along with } \\
\text { IL-15 }\end{array}$ & $\begin{array}{c}\text { Breast } \\
\text { carcinoma }\end{array}$ & {$[64]$} \\
\hline 2012 & Tassev et al. & HLA-A2 EBNA3C & $\mathrm{CD} 8 \alpha \mathrm{TM} / \mathrm{CD} 137 / \mathrm{CD} 3 \zeta$ & Retrovirus & $\begin{array}{l}\text { EBV-positive T } \\
\text { cells }\end{array}$ & [65] \\
\hline 2012 & Esser et al. & GD2 & $\mathrm{mCD} 8 \alpha$ hinge $/ \mathrm{CD} 3 \zeta$ & Amphotropicvirus & Neuroblastoma & [66] \\
\hline 2013 & Zhang et al. & $\begin{array}{l}\text { HLA-2 complex- } \\
\text { associated gp100 } \\
\text { peptide }\end{array}$ & A2 TM/CD3 & Transfection & Melanoma & [67] \\
\hline 2015 & Töpfer et al. & PSCA & $\begin{array}{c}\text { CD28 hinge/CD28 } \\
\text { TM/CD3乙 DAP12 cell TM } \\
\text { and signaling }\end{array}$ & $\begin{array}{c}\text { Lentivirus in YTSNK } \\
\text { cells and primary NK } \\
\text { cells }\end{array}$ & $\begin{array}{l}\text { Solid Tumors } \\
\text { prostate cancer }\end{array}$ & {$[68]$} \\
\hline 2015 & Schönfled et al. & $\begin{array}{c}\text { ErbB2 } \\
\text { (HER-2) }\end{array}$ & 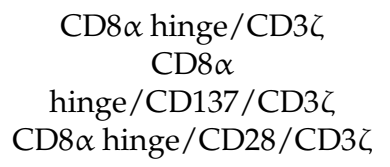 & Lentivirus & $\begin{array}{l}\text { Tumors of } \\
\text { epithelial origin }\end{array}$ & [69] \\
\hline 2015 & Liu et al. & $\begin{array}{c}\text { ErbB2 } \\
(\mathrm{HER}-2)\end{array}$ & CD8 $\alpha$ hinge/CD28/CD3 $\zeta$ & Transfections & $\begin{array}{c}\text { Breast } \\
\text { carcinoma }\end{array}$ & {$[70]$} \\
\hline
\end{tabular}


Table 1. Cont.

\begin{tabular}{|c|c|c|c|c|c|c|}
\hline Year & Researcher & Target & CAR Construct & Method & Tumor Targets & Ref \\
\hline 2014 & Jiang et al. & CD138 & $\mathrm{CD} 8 \alpha$ hinge/CD3 & Lentivirus & $\begin{array}{l}\text { Multiple } \\
\text { myeloma }\end{array}$ & [66] \\
\hline 2014 & Chu & CS1 & $\begin{array}{c}\mathrm{CD} 28 \mathrm{TM} / \mathrm{CD} 28 / \\
\mathrm{CD} 3 \zeta\end{array}$ & Lentivirus & $\begin{array}{l}\text { Multiple } \\
\text { myeloma }\end{array}$ & [16] \\
\hline 2013 & Boissel & CD19/CD20 & $\mathrm{CD} 3 \zeta$ & Lentivirus & $\begin{array}{l}\text { Lymphoblastic } \\
\text { leukemia }\end{array}$ & {$[44]$} \\
\hline 2012 & Boissel & CD19/CD20 & $\mathrm{CD} 3 \zeta$ & $\begin{array}{c}\text { mRNA transfection } \\
(30-70 \%) \text { and } \\
\text { lentivirus }\end{array}$ & $\begin{array}{l}\text { Lymphoblastic } \\
\text { leukemia }\end{array}$ & [71] \\
\hline
\end{tabular}

Table 2. Current CAR-NK clinical trials.

\begin{tabular}{|c|c|c|c|c|c|c|c|c|}
\hline Year & $\begin{array}{l}\text { Cell } \\
\text { Line }\end{array}$ & Phase & Disease & $\begin{array}{l}\text { Clinical } \\
\text { Trial Nos }\end{array}$ & $\begin{array}{l}\text { Sponsors and } \\
\text { Collaborator }\end{array}$ & Study Type & Gender & $\begin{array}{l}\text { Study } \\
\text { Design }\end{array}$ \\
\hline 2009-2016 & $\begin{array}{l}\text { NK-92 } \\
\text { cells }\end{array}$ & Phase I & $\begin{array}{c}\text { Acute myeloid } \\
\text { leukemia }\end{array}$ & $\begin{array}{c}\text { NCT00900809 } \\
{[57]}\end{array}$ & $\begin{array}{l}\text { University of } \\
\text { Pittsburgh } \\
\text { ZelleRX } \\
\text { Corporation }\end{array}$ & Interventional & Both & Treatment \\
\hline 2005-2016 & $\begin{array}{l}\text { NK-92 } \\
\text { cells }\end{array}$ & Phase I & $\begin{array}{l}\text { Leukemia } \\
\text { Lymphoma } \\
\text { myeloma } \\
\text { Hodgkin's } \\
\text { disease }\end{array}$ & $\begin{array}{c}\text { NCT00990717 } \\
\text { [72] }\end{array}$ & $\begin{array}{l}\text { University } \\
\text { Health } \\
\text { Network, } \\
\text { Toronto }\end{array}$ & Interventional & Both & Treatment \\
\hline 2009-2015 & $\begin{array}{l}\text { NK Cell } \\
\text { Infusion }\end{array}$ & Phase I & $\begin{array}{l}\text { Lymphoblastic } \\
\text { leukemia } \\
\text { Refractory } \\
\text { B-lineage acute } \\
\text { lymphoblastic } \\
\text { leukemia } \\
\text { (ALL) }\end{array}$ & $\begin{array}{l}\text { NCT00995137 } \\
\text { [73] } \\
\text { David Shook, } \\
\text { MD }\end{array}$ & $\begin{array}{c}\text { St.Jude } \\
\text { Children's } \\
\text { Research } \\
\text { Hospital } \\
\text { National } \\
\text { Cancer } \\
\text { Institute (NCI) } \\
\text { Assisi } \\
\text { Foundation }\end{array}$ & $\begin{array}{c}\text { Interventional } \\
\text { (NK cell } \\
\text { infusion) }\end{array}$ & Both & Treatment \\
\hline 2013-2017 & $\begin{array}{l}\text { NK Cell } \\
\text { Infusion }\end{array}$ & Phase I & $\begin{array}{c}\text { B-cell } \\
\text { lymphoma, } \\
\text { non-Hodgkin, } \\
\text { lymphoprolif- } \\
\text { erative } \\
\text { disorders, } \\
\text { neoplasms }\end{array}$ & $\begin{array}{c}\text { NCT01974479 } \\
\text { [74] } \\
\text { Dario } \\
\text { Campana }\end{array}$ & $\begin{array}{l}\text { National } \\
\text { University } \\
\text { Health System, } \\
\text { Singapore } \\
\text { Singapore } \\
\text { General } \\
\text { Hospital }\end{array}$ & $\begin{array}{l}\text { Interventional } \\
\text { (anti-CD19 } \\
\text { redirected } \\
\text { NK cells) }\end{array}$ & Both & Treatment \\
\hline
\end{tabular}

\subsection{NK Cells Derived from Peripheral Blood}

The majority of clinical trials have preferred NK cells from peripheral blood mononuclear cells (PBMCs). Due to the abundant source of CD16+ and CD56+ mature and functional NK cells in peripheral blood of healthy individuals, the focus of isolating NK cells has become dependent on leukapheresis. Briefly, lymphocytes can be enriched from whole blood using density gradient centrifugation [75]. Various companies have manufactured NK cell isolation kits based on immunomagnetic bead particles. These bead-based products usually come in different formats. First, the "touched" kit (positive selection) is based upon antibodies that bind specifically to NK cells such as CD56, and the remaining nonbound lymphocytes are cleared through wash buffer [76]. Further CD56-bound NK cells are 
enriched with buffer during washing steps. The second method of enrichment of NK cells is through "untouched" kits (negative selection), where a cocktail of antibodies binds all lymphocytes except CD56 (NK cells). The bound lymphocytes and monocytes other than NK cells are separated by immunomagnetic bead particles. Another method, which is in practice, takes advantage of the CD3 depletion kit, followed by CD56 enrichment to obtain a highly purified population from humanized mice, as well as PBMCs [77]. PBMCs NK cells, which are found in the steady state, require cytokines for activation to elicit enhanced cytotoxicity against tumor cells [45]. These chemokine-activated killer cells are a combination of $\mathrm{T}$ cells and NK cells [78,79]. Various modified culturing conditions have been used for activation of NK cells with a specific focus on maintaining in vivo cell survival and enhancing cell cytotoxicity. In addition to IL-2, IL-15 has been explored to mediate NK cell activation and cytotoxicity following post-cytokine withdrawal [80,81]. Other cytokines such as IL-12 and IL-18 were used to reverse the exhaustion caused due to IL-2 and expansion of NK cells in immunodeficient mice. The combination of IL-15 with IL-12 and IL-18 led to the induction of NK cells, as well as preferential induction of memory NK cells [46]. Similarly, the combination of the aforementioned cocktail of cytokines with IL-2 led to enhanced restimulation with greater IFN- $\gamma$ production and greater cytotoxicity [52]. Early studies using primary NK cells transduced with anti-CD19-BBz and cocultured with K562 expressing membrane-bound IL-15 and costimulatory molecule 4-1BB (K562-mb15-41BBL) showed improved stimulation of NK cells and an amplification of NK cells within one week of culturing [53]. Addition of the 4-1BB costimulatory molecule to the chimeric anti-CD19-CD3zeta receptor not only improved stimulation but resulted in higher cytotoxicity compared to that of NK cells, which lacked these molecules. With increased activation, significant production of IFN- $\gamma$ and granulocyte-macrophage colony-stimulating factor (GM-CSF) was observed in modified NK cells.

\subsection{Immortalized Cells Lines as a Source of NK Cells}

Addition of CAR expression to existing NK-cell-activating receptors could enhance NK cell ability to eliminate targeted tumor cells, especially in solid tumors that are often resistant to NK-cell-mediated killing. The feasibility of CAR-NKs has recently been explored, mostly in defined NK cell lines, such as NK-92 [43,76]. The NK-92 cell line has the advantage of being a homogenous cell population compared to mixed subsets isolated from a normal healthy donor. Although the NK-92 cell line is well defined, it has several disadvantages. It lacks expression of typical NK-cell-activating receptors such as CD16, and other NCR expression markers such as NKp30, NKp46, and NKGD are present. Additionally, NK-92 cells are tumor cell lines with multiple cytogenetic abnormalities and are latently infected with Epstein-Barr virus, which necessitates irradiation for safety measures before infusion [54]. Considering all advantages and disadvantages, NK-92 is the only cell line that is currently being employed in clinical trials (NCT00900809 and NCT00990717) [53]. Several other cell lines, including NK-YS, NKG, NKL, and haNK-1 cells, are being tested in preclinical models [82]. Most of the studies for CAR-NKs in NK-92 cells were performed using first-generation CAR constructs, which contain CD3 as their sole signaling domain. The scFv of these CARs target CD20 [62], CD19 [63], Erb, HER2 [61,83], GD2 [84], and CD138 [70].

CAR studies targeting B-cell malignancies with CD19 and CD20 have extensively used $T$ cells. Some studies reported the use of $C D 3 \zeta$, and some used CD8 [62] as a transmembrane domain in the CAR construct. The ADCC function of NK-92 anti-CD20-CAR was more effective than NK-92 plus rituximab in primary CLL cells [66]. These NK-92 cells were specifically engineered to express CD16 to perform ADCC functions. Preclinical models for B-cell malignancies have shown promising results. NK-92 cells engineered to target CD19 (construct NK92-CD19-CD3- $\zeta$ ) showed cell cytotoxicity and enhanced killing of tumor cells. Similarly, transfection of peripheral blood NK (PB-NK) with the mRNA construct of CD20-41BB-CD3- $\zeta$ was used to generate another NK-CAR. These were activated by coculturing with modified K562 expressing IL-15-41BBL, which has been reported 
to enhance cytotoxicity to resistant Burkitt lymphoma. In vivo studies indicated better survival of mice [44]. Acute myelogenous leukemia (AML) cells lines are less resistant than solid tumors to the cytolytic activity of effector cells targeting cognate specific epitope on tumor cells [16].

In a solid tumor model, HER-2-positive breast, ovarian, and squamous cell carcinoma were successfully targeted by constructs with anti-Erb2 CAR in NK-92 cells, which had improved cytotoxicity and reduced tumor growth [61]. An anti-GD2 CAR-NK was able to target glioblastoma, melanoma, and breast carcinoma [66]. In mouse studies with a multiple myeloma (MM) tumor model, NK-92 cells expressing anti-CD138 CAR-NK had significantly longer survival compared to NK-92 alone [70]. This demonstrates that NK-92, along with first-generation CARs, produces effective target cell lysis in vitro, as well as in mouse models. However, most of these models are evaluated subcutaneously, which might not address all issues such as NK trafficking or environmental cues in various organs or tissues. Overall, NK cells could be an alternative to T cells for CAR-engineered therapy. Unlike T cells, which secrete TNF alpha, IFN- $\gamma$, IL-1, and IL-6, NK cells secrete IL-3, and GM-CSF, which are less likely to cause cytokine release syndrome (CRS) [85]. Most importantly, CAR-NK cells, as well as target tumor cells, have the ability to be recognized as a function of NK immunosurveillance, which may reduce tumor escape [86].

\subsection{NK Cells Derived from Cord Blood}

Umbilical cord blood (UCB) is a great source of stem cells, as well as lymphocytes. While NK cells account for $\sim 10-12 \%$ of total lymphocytes in PBMCs, $\sim 25-30 \%$ of lymphocytes in UCB are NK cells $[87,88]$. Thus, UCB is a rich source of NK cells (cord blood, CB-NK). An optimized protocol for CD34+ cell enrichment from cryopreserved UCB units has been established using the CliniMACS system, followed by an efficient expansion for 14 days in gas-permeable cell culture bags. These enriched CD34+ UCB cells are expanded, amplified, and differentiated into CD56pos CD3 neg NK cell products using bioreactors with a mean expansion of more than 2000 -fold and a purity of $>90 \%$. This expansion was significant and necessary for clinical studies, as this was a relevant dose of NK cells (mean: $2 \times 10^{9} \mathrm{NK}$ cells). All of these NK cells displayed high expressions of activating NK receptors, as well as retaining the ability to kill K562 cells [56].

Compared to PB-NK cells, CB-NK cells are less mature and therefore possess less cytotoxicity with low expression of CD16. Although CB-NK cells are less mature, the advantage of CB-NK is that they have tremendous potential for proliferation, and they respond to cytokine stimulus, which in turn eliminates the need for a feeder layer in production. One advantage of allogeneic NK cells over CAR-T cells is that they do not cause GvHD, as demonstrated in murine models [89], as well as clinical studies of haploidentical and CB-derived NK cell infusions for patients with hematological malignancies [16]. Rezvani's group recently conducted the first-in-human phase I/II clinical trial of CAR-NK cell therapy for patients with relapse/refractory (r/r) B-cell hematologic malignancies (NCT03056339). Here, the NK cells were derived from CB and were HLA mismatched with the recipient. The NK cells were retrovirally transduced to target against CD19, and the vector was infused with IL-15 to enhance NK cell persistence and function. For internal safety, an inducible caspase 9 suicide gene (iCas9) was installed to prevent excessive activation. In total, the vector is composed of construct CAR-CD19-CD28-zeta-2A-iCasp9-IL15-NK cells. Eight out of 11 patients responded to the treatment (three different dose levels, $1 \times 10^{5}, 1 \times 10^{6}$, or $1 \times 10^{7}$ cells per $/ \mathrm{kg}$ ). From these eight patients, seven achieved a complete remission (64\%). Additionally, no serious toxicities such as CRS, immune effector cell-associated neurotoxicity syndrome (ICANS), or GvHD were developed in any of the patients.

\subsection{NK Cells Derived from Induced Pluripotent Stem Cell}

Stem cells, especially induced pluripotent stem cells (iPSCs), have the advantage of providing an unlimited source of potentially functional NK cells. Unlike other sources, iPSC-derived NK (iNK) opens the potential for "off-the-shelf" products using an improved 
manufacturing pipeline process. The "off-the-shelf" products of immunotherapy have been evaluated to overcome the rate-limiting step of providing an unlimited source of NK cells. Studies describing the reprogramming of stem cells to achieve pluripotency in order to differentiate into an innate immune product such as NK cells and further develop into a final product have been described in detail elsewhere [90,91]. Miller et al. outlined a detailed study that describes a robust and efficient manufacturing system for the differentiation and expansion of high-quality NK cells derived from iPSCs. The iNK cells were shown to produce inflammatory cytokines and strong cytotoxicity effects against an array of hematologic and solid tumors. These iNK cells were found to recruit $\mathrm{T}$ cells and enabled them to respond to anti-PD- 1 antibodies. Furthermore, these iNK cells enhanced inflammatory cytokine production and tumor lysis activity. Bulk production of iNK cells from a single batch of adult stem cells can be achieved. This enables the manufacturing and production of large numbers of doses from a single manufacturer $[80,92]$. Hermanson et al. used an ovarian cancer xenograft model to evaluate the expansion of iPSC-derived NK cells and established the proof of concept of iNK cells effect against cold tumors (tumors which present low infiltration capacity, suppressing the immune response) [92].

In a similar study, Li et al. used CAR-NK cells with enhanced NK cell activity [58]. The CAR (construct NK-CAR-iPSC-NK cells) demonstrated an improved antitumor activity compared to T-CAR-expressing iPSC-derived NK cells (construct T-CAR-iPSC-NK cells). In this study, using an ovarian cancer xenograft model, NK-CAR-iPSC-NK cells supplemented with cytokines (IL-2 and rIL-15 for NK cells) were found to significantly inhibit tumor growth and prolong survival compared to PB-NK cells, iPSC-NK cells, or T-CAR-iPSC-NK cells. Furthermore, NK-CAR-iPSC-NK cells were found to be less toxic in vivo compared to T-CAR-expressing T cells. In this study, the mesothelin cell surface marker was targeted in an in vitro solid tumor model. These CAR-NK cells consisted of scFv for mesothelin, NKG2D as a transmembrane marker, a costimulating domain 2B4 (2B4D), and a stimulation domain $\mathrm{CD} 3 z$ (CD3zD). Overall cytotoxicity was measured through expression of CD107a and IFN- $\gamma$ production. The results indicated robust antitumor activity. To further evaluate the CAR-NK, a tumor-bearing human ovarian xenograft mouse model was treated with CAR-iPSC-NK, which showed a significant reduction in tumor burden and prolonged the survival of these mice compared to control-treated mice. Combined, these two studies highlight NK-CAR-iPSC-NK cells' potential as excellent candidates for standardized and targeted "off-the-shelf" lymphocytes for cancer immunotherapy [93]. One of the major hurdles of iNK expansion is the relatively low CD16 expression compared to PB-NK cells and therefore low cytotoxicity towards tumor cells. To overcome this limitation, iNK cells are engineered to enhance not only tumor surveillance but to improve persistence for clinical trials.

A biotechnology company, Fate Therapeutics (San Diego, CA, USA), has several iNK cells products that are currently being assessed in a phase 1 clinical trial. A phase I clinical trial (NCT03841110) with iNK cells (FT500) [94] as monotherapy in combination with immune checkpoint inhibitors has been initiated in patients with advanced solid tumors. Another investigational iNK cell product (FT516) [95], engineered to express a high-affinity, noncleavable CD16 Fc receptor (hnCD16Fc) designed to maximize antibody-dependent cytotoxicity, is also under phase 1 clinical investigation (NCT04023071) as a monotherapy against relapsed/refractory acute myeloid leukemia (AML) and in combination with CD20 directed monoclonal antibodies in advanced B-cell lymphoma [96]. The product, owing to its $\mathrm{hnCD} 16 \mathrm{Fc}$ receptor and CAR-targeting CD19, in addition to IL-15 receptor fusion, allows for the multiantigen targeting of tumor cells with enhanced NK cell activity and survival. Another of their products, FT596, is a first of its kind: "off-the-shelf" CAR-NK cells produced from iPSCs and targets the B-cell antigen CD19. FT596 expresses a novel and high-affinity 158V, noncleavable CD16 (hnCD16) Fc receptor, which has been modified to prevent its downregulation and to enhance its binding to tumor-targeting antibodies. NK cell activity was enhanced with the support of endogenously expressed cell surface IL-15 receptor fusion (IL-15RF). The CD19-CAR-iNK cells with hnCD16 and IL-15 fusion receptor 
showed promising preclinical data with high antitumor activity and in vivo persistence with no loss of cell surface CD16 (no cleavage). Increased degranulation and cytokine release were observed upon dual receptor activation in lymphoma cancer cells. This has led to phase I/II investigation for treating advanced B-cell malignancies (NCT04245722) [97].

Another biotechnology company, Cytovia Therapeutics (Miami, FL, USA), is targeting solid tumors with CAR-iNK cells. They are planning to use this platform of CAR-iNK for multiple clinical trials in the near future. Currently, their program consists of preclinical work, where the aim is to differentiate and expand NK cells from iPSCs. Furthermore, in collaboration with Cellectis, they are in the process of cell engineering for optimization of their design and performance through gene editing [98]. Here, they take advantage of gene edits through transcription activator-like effector nucleases (TALENs) $[98,99]$ to precisely edit/insert CAR into a certain gene location. Thus, the CAR insertion enables the highest functional persistence of NK cells, thereby improving their clinical efficacy and safety. Cytovia is also at the forefront of developing an NK cell engager making use of Nkp46 and targeting various other diseases. Their products of iNK, along with NK engagers, are a unique set of combinations of molecules targeting diseases. The product CYT-100 and CYT-150 are in preclinical trials, where they use universal iNK cells, along with NK cell engagers, both targeting solid tumors. Other products such as CYT-338 and CYT-538 target multiple myeloma, whereas CYT-501 targets glioblastoma through antigen EGFRvII+wt [100].

Additionally, unlike the persistence of CAR-T cells targeting CD19, which cause prolonged cytopenia, the shorter life span of mature NK cells provides an effective antitumor killing capacity with a reduced probability of long-term on-target/off-tumor effects. The antitumor activity of CAR-NK is not only executed through CAR, which has the capacity to specifically recognize antigen-expressing tumors, but also through its own cognate cell receptors.

\section{Novel Bispecific Antibodies or Single-Chain Variable Fragment Targeting NK Cells}

Other ways to redirect NK cell cytotoxicity towards tumor cells is through bispecific and/or trispecific engagers (BiKE, TriKE) [101]. Construction of specific targeting molecules involves combining a scFv against $\mathrm{CD} 16$ and a scFv against a tumor-associated antigen (BiKE) or two tumor-associated antigens (TriKE). The proof of principle was provided with NK cell bsFv bispecific CD16/CD19 and trispecific tsFv CD16/CD19/CD22 engagers that were activated through CD16. This led to enhanced cytotoxic killing and cytokine production against various CD19-expressing B-cell lines [101]. A CD33xCD16 BiKE was developed against AML and demonstrated that killing by NK cells could be achieved [102]. During the activation of NK cells, gradual loss of CD16 and CD62L was observed. It was determined that ADAM metallopeptidase domain 17 (ADAM17), a metalloprotease that is expressed in NK cells, may in turn impact the efficacy of Fc-mediated cytotoxicity by shedding CD16 [64]. Selective inhibition of ADAM17 prevented the shedding of CD16 and in turn increased CD16-mediated killing and restored the functionality of NK cells by preserving cell surface expression of CD16.

\subsection{Bispecific NK Cell Engager (BiKE) \\ 6.1.1. $\mathrm{CD} 16 \mathrm{xCD} 33$}

NK cells have also been redirected to target myelodysplastic syndrome (MDS) by engaging CD16 (Fc $\gamma$ RIII) on the NK cell and CD33 on the MDS cells. In a study of blood and bone marrow (BM) from 67 patients with MDS, CD16xCD33 BiKE elicited enhanced deregulation and cytokine production of TNF- $\alpha$ and IFN $\gamma$ against HL-60 and endogenous CD33+ MDS targets [101]. This treatment used IL-2 to expand NK cells, but unfortunately, IL-2 also induced Tregs that indirectly inhibited NK cell proliferation. Despite this, reverse ADCC assays showed potent degranulation and cytokine production when resting MDSNK cells were triggered with an agonistic CD16 monoclonal antibody. The collected blood and BM MDS-NK cells treated with this bispecific killer cell engager (BiKE) showed 
significantly enhanced degradation and TNF- $\alpha$ and IFN- $\gamma$ production against HL-60 and endogenous CD33+ MDS targets. MDS patients have been known to present an increased proportion of immunosuppressive CD33+ myeloid-derived suppressor cells (MDSCs), which negatively correlated with MDS lymphocyte populations and CD16 loss on NK cells. Treatment with the CD16xCD33 BiKE successfully reversed MDSC immunosuppression of NK cells and induced MDSC targeted cell lysis. Lastly, the BiKE induced optimal MDS-NK cell function irrespective of disease stage. These data suggested that the CD16xCD33 BiKE functions against both CD33+ MDS and MDSC targets and might be therapeutically beneficial for MDS patients.

To overcome the limitation of IL-2-mediated Treg suppression, a second-generation molecule incorporates the cytokine IL-15, which is the homeostatic factor for NK cell proliferation, survival, activation, and development [103], into a trispecific killer engager (TriKE). In short, TriKE molecules consist of three major arms: first, a scFv against CD16 of NK cells, to trigger NK cell activation; second, an $\mathrm{scFv}$ against a tumor-associated antigen, to induce specific tumor target recognition; and third, a cytokine IL-15 moiety, to trigger NK cell expansion and priming. In this study, Martin et al. targeted CD33 through TriKE, engaging CD16 on NK cells. The study highlighted that an improved TriKE using a modified anti-CD16 scFv with a humanized single-domain antibody against CD16 exhibited higher functionality. With such a second-generation TriKE that targeted CD33, the authors showed these TriKEs can induce stronger and more specific NK cell proliferation. In a preclinical tumor model, NK cells exhibited enhanced in vitro activation and killing of CD33-expressing targets. The promising outcome provides a framework for future clinical trials [65].

An off-the-shelf 161533 TriKE molecule, containing scFvs against CD16 and CD33, could engage both natural killer (NK) cells and myeloid cells, whereas a human-modified interleukin-15 (IL-15) linker that links the two scFvs, was found to impart potential immunomodulating and antineoplastic activities against CD33-expressing tumor cells [67]. Compared to CD16xCD33 BiKE, this TriKE showed greater target-specific TNF $\alpha$, IFN- $\gamma$, IL-6, macrophage inflammatory (MIP1 $\alpha$ ), GM-CSF, and IL-18 production against HL60 target cells. The in vivo xenogeneic experiments with the adoptive transfer of human NK cells into NSG mice engrafted with HL60 showed that the TriKE had significant antitumor activity without any major toxicities [68]. Details of BiKEs and TriKEs are comprehensively discussed in another review [104].

\subsubsection{CD30/CD16A}

AFM13 is a bispecific (CD30/CD16A) tetravalent chimeric antibody construct (Tand Ab) that specifically targets CD30 in Hodgkin lymphoma (HL) cells and recruits and activates NK cells by binding to CD16A. It engages NK cells through CD16A with high affinity and specificity and confers significantly stronger NK cell activation compared to other therapeutic antibodies. AFM13 specifically enhances the cytotoxic, proliferative capacity, and cytokine-producing potential of NK cells. Preclinical data for AFM13 (CD16A/CD30) demonstrated that AFM13 strongly binds to NK cells, including cytokine-activated or cordblood-derived NK (CB-NK) cells, resulting in enhanced tumor recognition and antibodydependent cellular cytotoxicity (ADCC) [69]. Combination with low doses of IL-2 or with IL-15 may expand the quantity of tumor-reactive NK cells after AFM13 treatment and promote NK cell functionality in TME in cancer patients. Preclinical in vivo data of the combination of AFM13 with PD-1 suggests synergistic activity and the potential for induction of cross-talk between innate and adaptive immunity [105]. Reduction of tumor growth was strongly correlated with infiltrating NK and T cells and intratumoral cytokines. A Phase I study of the combination of AFM13 and anti-PD1 antibody, pembrolizumab, for the treatment of patients with $\mathrm{r} / \mathrm{r}$ Hodgkin lymphoma has been planned. 


\section{Limitations}

Although the field of NK cell immunotherapy has made significant progress from preclinical studies to clinical infusion of adoptively transferred NK cells, there are some immediate concerns that need to be addressed to enhance this therapy. The primary NK cells isolated from PBMCs are difficult to maintain in vitro, largely due to the short lifespan of NK cells. Efforts have been made to provide cytokine support such as IL-15 or IL-12 or a combination of other cytokines for the maintenance and persistence of NK cells in vivo. Components that act as negative regulators for IL-15 could impede the enhancement of NK effector function. CRISPR/Cas9-mediated deletion of a negative regulator of checkpoint inhibitor CISH in pluripotent stem cells at an early stage of NK cell biogenesis resulted in higher NK-cell-mediated cytotoxicity against target cells [106]. These cells had better in vivo persistence, cytotoxicity, and eradication of the target AML xenograft compared to the control. Additional efforts are being made to reverse the exhaustion of NK cells. Modified NK cells are provided with combinations of checkpoint blockade antibodies such as anti-TIM3, anti-PD1, and anti-TIGIT (T-cell immunoreceptor with Ig and ITIM domains) that lead to improved antitumor responses [71].

\section{Future and Discussion}

The future of clinical trials depends on many factors-most importantly, the trial design. NK cell immunotherapies, which harness the power of NK cells, have shown promising results and are complementary to T-cell therapies. Recent advances in gene manipulation have allowed for the creation of novel CAR-NK cell products with enhanced antitumor response [25]. The clinical trials of pleiotropic CAR-NK, which have gained a lot of attention, have begun to investigate the potential of this type of cancer immunotherapy. Similar to T cells, the engineering of NK cells continues to face difficulties such as safety, clinical efficacy, homing, dose replications, and in vivo persistence after treatment. Various modes of drug delivery, including lipid nanoparticles (LPNs) and liposomes, are currently being explored for use in adoptive transfer modalities. Briefly, LPNs are composed of ionizable lipid, a cholesterol moiety, and an additional helper phospholipid and lipidanchorage polyethylene-glycol conjugate to minimize LPN aggregation [107]. Margert et al. reported LPNs designed for ex vivo mRNA delivery to human T cells. Several ionizable lipids were produced and then formulated into LPNs. They were further used to deliver mRNA to Jurkat cells, and some formulations were capable of enhancing mRNA delivery over lipofectamine. One of the LPN formulations was further selected to deliver CAR mRNA into primary human T cells. CAR-T cells engineered with the LPN method were then compared to electroporated (EP) CAR-T cells in a coculture assay with the Nalm6 cell line, where CAR-T cells engineered via both these methods showed pronounced antitumor activity. Overall, this report signifies the importance of an alternate delivery method of mRNA to primary human T cells through LPN which can induce functional protein expression, as well as enhance mRNA-based CAR-T cells. Further investigation is required for the ability of LPNs to deliver cargo in TME and expression patterns in solid tumors [108].

Ultimately, the goal has been to provide an "off-the-shelf" product, which is considered nontoxic to normal healthy tissues after being adoptively infused into patients. The goal further covers the product that could be delivered to all HLA haplotypes without the occurrence of GvHD. Modification of iPSCs with CRISPR technology or inclusion of novel genes to improvise persistence of CAR-NK in TME are some of the key innovations moving forward. The reprogramming of CAR-NKs to overcome tumor suppression and escape is instrumental for the clinical outcome of NK therapies. Suitable gene modification along with biomanufacturing and banking processes will require further intricate optimization. Exploration for more optimal strategies and broad-range tumor targets for solid tumors is required. Manifestations of all these efforts are primarily aimed to avoid off-target cytotoxicity. 
Author Contributions: P.V. and S.K.H. conceived the study, V.K. and D.L.S. edited and provided professional input of the review. P.V. has drafted this review. All authors have read and agreed to the published version of the manuscript.

Funding: This research received no external funding.

Acknowledgments: Aashish Pande is acknowledged for his contribution to designing the figures and Trupti Palav, Krystal Valdenegro, and Shiny Nair for editing the manuscript.

Conflicts of Interest: The authors declare no conflict of interest.

\section{References}

1. Kiessling, R.; Klein, E.; Pross, H.; Wigzell, H. "Natural” killer cells in the mouse. II. Cytotoxic cells with specificity for mouse Moloney leukemia cells. Characteristics of the killer cell. Eur. J. Immunol. 1975, 5, 117-121. [CrossRef]

2. Herberman, R.B.; Nunn, M.E.; Lavrin, D.H. Natural cytotoxic reactivity of mouse lymphoid cells against syngeneic acid allogeneic tumors. I. Distribution of reactivity and specificity. Int. J. Cancer 1975, 16, 216-229. [CrossRef]

3. Imai, K.; Matsuyama, S.; Miyake, S.; Suga, K.; Nakachi, K. Natural cytotoxic activity of peripheral-blood lymphocytes and cancer incidence: An 11-year follow-up study of a general population. Lancet 2000, 356, 1795-1799. [CrossRef]

4. Vesely, M.D.; Kershaw, M.H.; Schreiber, R.D.; Smyth, M.J. Natural Innate and Adaptive Immunity to Cancer. Annu. Rev. Immunol. 2011, 29, 235-271. [CrossRef]

5. Vivier, E.; Ugolini, S.; Blaise, D.; Chabannon, C.; Brossay, L. Targeting natural killer cells and natural killer T cells in cancer. Nat. Rev. Immunol. 2012, 12, 239-252. [CrossRef] [PubMed]

6. Klingemann, H.G. Cellular therapy of cancer with natural killer cells-where do we stand? Cytotherapy 2013, 15, 1185-1194. [CrossRef]

7. A Geller, M.; Miller, J.S. Use of allogeneic NK cells for cancer immunotherapy. Immunotherapy 2011, 3, 1445-1459. [CrossRef] [PubMed]

8. Michel, T.; Poli, A.; Cuapio, A.; Briquemont, B.; Iserentant, G.; Ollert, M.; Zimmer, J. Human CD56bright NK Cells: An Update. J. Immunol. 2016, 196, 2923-2931. [CrossRef]

9. Poli, A.; Michel, T.; Thérésine, M.; Andrès, E.; Hentges, F.; Zimmer, J. CD56bright natural killer (NK) cells: An important NK cell subset. Immunology 2009, 126, 458-465. [CrossRef]

10. Gasser, S.; Raulet, D.H. Activation and self-tolerance of natural killer cells. Immunol. Rev. 2006, 214, 130-142. [CrossRef] [PubMed]

11. Orr, M.; Lanier, L.L. Natural Killer Cell Education and Tolerance. Cell 2010, 142, 847-856. [CrossRef]

12. Vivier, E.; Raulet, D.H.; Moretta, A.; Caligiuri, M.A.; Zitvogel, L.; Lanier, L.L.; Yokoyama, W.M.; Ugolini, S. Innate or Adaptive Immunity? The Example of Natural Killer Cells. Science 2011, 331, 44-49. [CrossRef]

13. Sun, J.C.; Lanier, L.L. NK cell development, homeostasis and function: Parallels with CD8+ T cells. Nat. Rev. Immunol. 2011, 11, 645-657. [CrossRef]

14. O'Leary, J.G.; Goodarzi, M.; Drayton, D.L.; von Andrian, U.H. T Cell- and B Cell-Independent Adaptive Immunity Mediated by Natural Killer Cells. Nat. Immunol. 2006, 7, 507-516. Available online: https://www.nature.com/articles/ni1332 (accessed on 26 September 2021). [CrossRef]

15. Paust, S.; Gill, H.S.; Wang, B.Z.; Flynn, M.P.; Moseman, E.A.; Senman, B.; Szczepanik, M.; Telenti, A.; Askenase, P.W.; Compans, R.W.; et al. Critical Role for the Chemokine Receptor CXCR6 in NK Cell-Mediated antigen-Specific Memory of Haptens and Viruses. Nat. Immunol. 2010, 11, 1127-1135. Available online: https://www.nature.com/articles/ni.1953 (accessed on 26 September 2021). [CrossRef]

16. Rezvani, K.; Rouce, R.; Liu, E.; Shpall, E. Engineering Natural Killer Cells for Cancer Immunotherapy. Mol. Ther. 2017, 25, 1769-1781. [CrossRef]

17. Dianat-Moghadam, H.; Rokni, M.; Marofi, F.; Panahi, Y.; Yousefi, M. Natural killer cell-based immunotherapy: From transplantation toward targeting cancer stem cells. J. Cell Physiol. 2018, 234, 259-273. [CrossRef]

18. Guillerey, C.; Huntington, N.D.; Smyth, M.J. Targeting natural killer cells in cancer immunotherapy. Nat. Immunol. 2016, 17, 1025-1036. [CrossRef] [PubMed]

19. Ruggeri, L.; Capanni, M.; Mancusi, A.; Urbani, E.; Perruccio, K.; Burchielli, E.; Tosti, A.; Topini, F.; Aversa, F.; Martelli, M.F.; et al. Alloreactive natural killer cells in mismatched hematopoietic stem cell transplantation. Blood Cells Mol. Dis. 2004, 33, $216-221$. [CrossRef]

20. Alter, G.; Malenfant, J.; Altfeld, M. CD107a as a functional marker for the identification of natural killer cell activity. J. Immunol. Methods 2004, 294, 15-22. [CrossRef]

21. Fogel, L.A.; Sun, M.M.; Geurs, T.L.; Carayannopoulos, L.N.; French, A.R. Markers of Nonselective and Specific NK Cell Activation. J. Immunol. 2013, 190, 6269-6276. [CrossRef] [PubMed]

22. Vivier, E.; Anfossi, N. Inhibitory NK-cell receptors on T cells: Witness of the past, actors of the future. Nat. Rev. Immunol. 2004, 4, 190-198. [CrossRef]

23. Morgan, M.A.; Büning, H.; Sauer, M.; Schambach, A. Use of Cell and Genome Modification Technologies to Generate Improved "Off-the-Shelf" CAR T and CAR NK Cells. Front. Immunol. 2020, 11, 1965. [CrossRef] [PubMed] 
24. Yu, J.; Freud, A.G.; Caligiuri, M.A. Location and cellular stages of natural killer cell development. Trends Immunol. 2013, 34, 573-582. [CrossRef]

25. Bald, T.; Krummel, M.F.; Smyth, M.J.; Barry, K.C. The NK cell-cancer cycle: Advances and new challenges in NK cell-based immunotherapies. Nat. Immunol. 2020, 21, 835-847. [CrossRef]

26. Corat, M.A.F.; Schlums, H.; Wu, C.; Theorell, J.; Espinoza, D.A.; Sellers, S.E.; Townsley, D.M.; Young, N.S.; Bryceson, Y.T.; Dunbar, C.E.; et al. Acquired somatic mutations in PNH reveal long-term maintenance of adaptive NK cells independent of HSPCs. Blood 2017, 129, 1940-1946. [CrossRef] [PubMed]

27. Zhang, Y.; Wallace, D.L.; De Lara, C.M.; Ghattas, H.; Asquith, B.; Worth, A.; Griffin, G.E.; Taylor, G.P.; Tough, D.F.; Beverley, P.C.; et al. In vivo kinetics of human natural killer cells: The effects of ageing and acute and chronic viral infection. Immunology 2007, 121, 258-265. [CrossRef] [PubMed]

28. Rosenberg, S.A.; Lotze, M.T.; Muul, L.M.; Leitman, S.; Chang, A.E.; Ettinghausen, S.E.; Matory, Y.L.; Skibber, J.M.; Shiloni, E.; Vetto, J.T. Observations on the systemic administration of autologous lymphokine-activated killer cells and recombinant interleukin-2 to patients with metastatic cancer. N. Engl. J. Med. 1985, 313, 1485-1492. [CrossRef] [PubMed]

29. Burns, L.J.; Weisdorf, D.J.; DeFor, T.E.; Vesole, D.H.; Repka, T.L.; Blazar, B.R.; Burger, S.R.; Panoskaltsis-Mortari, A.; Keever-Taylor, C.A.; Zhang, M.J.; et al. IL-2-based immunotherapy after autologous transplantation for lymphoma and breast cancer induces immune activation and cytokine release: A phase I/II trial. Bone Marrow Transplant. 2003, 32, 177-186. [CrossRef] [PubMed]

30. Walewski, J.; Paietta, E.; Dutcher, J.; Wiernik, P.H. Evaluation of natural killer and lymphokine-activated killer (LAK) cell activity in vivo in patients treated with high-dose interleukin-2 and adoptive transfer of autologous LAK cells. J. Cancer Res. Clin. Oncol. 1989, 115, 170-174. [CrossRef]

31. Benyunes, M.C.; Higuchi, C.; York, A.; Lindgren, C.; A Thompson, J.; Buckner, C.D.; Fefer, A. Immunotherapy with interleukin 2 with or without lymphokine-activated killer cells after autologous bone marrow transplantation for malignant lymphoma: A feasibility trial. Bone Marrow Transplant. 1995, 16, 283-288.

32. Ni, J.; Miller, M.; Stojanovic, A.; Cerwenka, A. Toward the next generation of NK cell-based adoptive cancer immunotherapy. Oncoimmunology 2013, 2, e23811. [CrossRef]

33. Stern, M.; Passweg, J.R.; Meyer-Monard, S.; Esser, R.; Tonn, T.; Soerensen, J.; Paulussen, M.; Gratwohl, A.; Klingebiel, T.; Bader, P.; et al. Pre-emptive immunotherapy with purified natural killer cells after haploidentical SCT: A prospective phase II study in two centers. Bone Marrow Transplant 2013, 48, 433-438. [CrossRef]

34. Sun, C.; Sun, H.; Zhang, C.; Tian, Z. NK cell receptor imbalance and NK cell dysfunction in HBV infection and hepatocellular carcinoma. Cell. Mol. Immunol. 2014, 12, 292-302. [CrossRef] [PubMed]

35. Watanabe, M.; Kono, K.; Kawaguchi, Y.; Mizukami, Y.; Mimura, K.; Maruyama, T.; Izawa, S.; Fujii, H. NK cell dysfunction with down-regulated CD16 and up-regulated CD56 molecules in patients with esophageal squamous cell carcinoma. Dis. Esophagus 2010, 23, 675-681. [CrossRef]

36. Izawa, S.; Kono, K.; Mimura, K.; Kawaguchi, Y.; Watanabe, M.; Maruyama, T.; Fujii, H. $\mathrm{H}_{2} \mathrm{O}_{2}$ production within tumor microenvironment inversely correlated with infiltration of CD56(dim) NK cells in gastric and esophageal cancer: Possible mechanisms of NK cell dysfunction. Cancer Immunol. Immunother. 2011, 60, 1801-1810. [CrossRef] [PubMed]

37. Sinicrope, F.A.; Rego, R.L.; Ansell, S.M.; Knutson, K.L.; Foster, N.R.; Sargent, D.J. Intraepithelial effector (CD3+)/regulatory (FoxP3+) T-cell ratio predicts a clinical outcome of human colon carcinoma. Gastroenterology 2009, 137, 1270-1279. [CrossRef] [PubMed]

38. Hartigan-O'Connor, D.J.; Poon, C.; Sinclair, E.; McCune, J.M. Human CD4+ regulatory T cells express lower levels of the IL-7 receptor alpha chain (CD127), allowing consistent identification and sorting of live cells. J. Immunol. Methods 2007, $319,41-52$. [CrossRef]

39. Ghiringhelli, F.; Ménard, C.; Terme, M.; Flament, C.; Taieb, J.; Chaput, N.; Puig, P.E.; Novault, S.; Escudier, B.; Vivier, E.; et al. CD4+CD25+ regulatory T cells inhibit natural killer cell functions in a transforming growth factor-beta-dependent manner. J. Exp. Med. 2005, 202, 1075-1085. [CrossRef]

40. Moretta, L.; Moretta, A. Unravelling natural killer cell function: Triggering and inhibitory human NK receptors. EMBO J. 2003, 23, 255-259. [CrossRef] [PubMed]

41. Colonna, M.; Navarro, F.; Bellón, T.; Llano, M.; García, P.; Samaridis, J.; Angman, L.; Cella, M.; López-Botet, M. A common inhibitory receptor for major histocompatibility complex class I molecules on human lymphoid and myelomonocytic cells. J. Exp. Med. 1997, 186, 1809-1818. [CrossRef]

42. Berg, M.; Lundqvist, A.; McCoy, P.; Samsel, L.; Fan, Y.; Tawab, A.; Childs, R. Clinical-grade ex vivo-expanded human natural killer cells up-regulate activating receptors and death receptor ligands and have enhanced cytolytic activity against tumor cells. Cytotherapy 2009, 11, 341-355. [CrossRef] [PubMed]

43. Fujisaki, H.; Kakuda, H.; Shimasaki, N.; Imai, C.; Ma, J.; Lockey, T.; Eldridge, P.; Leung, W.H.; Campana, D. Expansion of Highly Cytotoxic Human Natural Killer Cells for Cancer Cell Therapy. Cancer Res. 2009, 69, 4010-4017. [CrossRef]

44. Miller, J.S.; Soignier, Y.; Panoskaltsis-Mortari, A.; McNearney, S.A.; Yun, G.H.; Fautsch, S.K.; McKenna, D.; Le, C.; DeFor, T.E.; Burns, L.J.; et al. Successful adoptive transfer and in vivo expansion of human haploidentical NK cells in patients with cancer. Blood 2005, 105, 3051-3057. [CrossRef] [PubMed] 
45. Leong, J.W.; Chase, J.; Romee, R.; Schneider, S.E.; Sullivan, R.P.; Cooper, M.; Fehniger, T.A. Preactivation with IL-12, IL-15, and IL-18 Induces CD25 and a Functional High-Affinity IL-2 Receptor on Human Cytokine-Induced Memory-like Natural Killer Cells. Biol. Blood Marrow Transplant. 2014, 20, 463-473. [CrossRef]

46. Ni, J.; Miller, M.; Stojanovic, A.; Garbi, N.; Cerwenka, A. Sustained effector function of IL-12/15/18-preactivated NK cells against established tumors. J. Exp. Med. 2012, 209, 2351-2365. [CrossRef]

47. Imamura, M.; Shook, D.; Kamiya, T.; Shimasaki, N.; Chai, S.M.H.; Coustan-Smith, E.; Imai, C.; Campana, D. Autonomous growth and increased cytotoxicity of natural killer cells expressing membrane-bound interleukin-15. Blood 2014, 124, 1081-1088. [CrossRef]

48. Barrett, D.M.; Singh, N.; Porter, D.L.; Grupp, S.A.; June, C.H. Chimeric Antigen Receptor Therapy for Cancer. Annu. Rev. Med. 2014, 65, 333-347. [CrossRef]

49. Park, J.H.; Brentjens, R.J. Adoptive immunotherapy for B-cell malignancies with autologous chimeric antigen receptor modified tumor targeted T cells. Discov. Med. 2010, 9, 277-288.

50. Hernández-López, A.; Téllez-González, M.A.; Mondragón-Terán, P.; Meneses-Acosta, A. Chimeric Antigen Receptor-T Cells: A Pharmaceutical Scope. Front. Pharmacol. 2021, 12, 720692. Available online: https://www.ncbi.nlm.nih.gov/pmc/articles/ PMC8417740/ (accessed on 26 September 2021). [PubMed]

51. Shimasaki, N.; Coustan-Smith, E.; Kamiya, T.; Campana, D. Expanded and armed natural killer cells for cancer treatment. Cytotherapy 2016, 18, 1422-1434. [CrossRef]

52. Imai, C.; Iwamoto, S.; Campana, D. Genetic modification of primary natural killer cells overcomes inhibitory signals and induces specific killing of leukemic cells. Blood 2005, 106, 376-383. [CrossRef]

53. Glienke, W.; Esser, R.; Priesner, C.; Suerth, J.D.; Schambach, A.; Wels, W.S.; Grez, M.; Kloess, S.; Arseniev, L.; Koehl, U. Advantages and applications of CAR-expressing natural killer cells. Front. Pharmacol. 2015, 6, 21. [CrossRef] [PubMed]

54. Tonn, T.; Schwabe, D.; Klingemann, H.G.; Becker, S.; Esser, R.; Koehl, U.; Suttorp, M.; Seifried, E.; Ottmann, O.G.; Bug, G. Treatment of patients with advanced cancer with the natural killer cell line NK-92. Cytotherapy 2013, 15, 1563-1570. [CrossRef] [PubMed]

55. Boissel, L.; Betancur, M.; Lu, W.; Wels, W.S.; Marino, T.; Van Etten, R.A.; Klingemann, H. Comparison of mRNA and lentiviral based transfection of natural killer cells with chimeric antigen receptors recognizing lymphoid antigens. Leuk. Lymphoma 2012, 53, 958-965. [CrossRef]

56. Olson, J.A.; Leveson-Gower, D.B.; Gill, S.; Baker, J.; Beilhack, A.; Negrin, R.S. NK cells mediate reduction of GVHD by inhibiting activated, alloreactive T cells while retaining GVT effects. Blood 2010, 115, 4293-4301. [CrossRef]

57. ImmunityBio, Inc. Phase I Study of Adoptive Immunotherapy Using the Natural Killer Cell Line, Neukoplast ${ }^{\mathrm{TM}}$ (NK-92), for the Treatment of Refractory or Relapsed Acute Myeloid Leukemia (Internet). Report No.: NCT00900809. Available online: https: / / clinicaltrials.gov/ct2/show / NCT00900809 (accessed on 7 October 2021).

58. Li, Y.; Hermanson, D.L.; Moriarity, B.S.; Kaufman, D.S. Human iPSC-Derived Natural Killer Cells Engineered with Chimeric Antigen Receptors Enhance Anti-tumor Activity. Cell Stem Cell 2018, 23, 181-192.e5. [CrossRef]

59. Knorr, D.A.; Ni, Z.; Hermanson, D.; Hexum, M.K.; Bendzick, L.; Cooper, L.J.; Lee, D.A.; Kaufman, D.S. Clinical-Scale Derivation of Natural Killer Cells from Human Pluripotent Stem Cells for Cancer Therapy. Stem Cells Transl. Med. 2013, 2, 274-283. [CrossRef]

60. Herrera, L.; Santos, S.; Vesga, M.A.; Anguita, J.; Martin-Ruiz, I.; Carrascosa, T.; Juan, M.; Eguizabal, C. Adult peripheral blood and umbilical cord blood NK cells are good sources for effective CAR therapy against CD19 positive leukemic cells. Sci. Rep. 2019, 9, 18729. [CrossRef]

61. Liu, H.; Yang, B.; Sun, T.; Lin, L.; Hu, Y.; Deng, M.; Yang, J.; Liu, T.; Li, J.; Sun, S.; et al. Specific growth inhibition of ErbB2expressing human breast cancer cells by genetically modified NK-92 cells. Oncol. Rep. 2014, 33, 95-102. [CrossRef] [PubMed]

62. Boissel, L.; Betancur, M.; Wels, W.S.; Tuncer, H.; Klingemann, H. Transfection with mRNA for CD19 specific chimeric antigen receptor restores NK cell mediated killing of CLL cells. Leuk. Res. 2009, 33, 1255-1259. [CrossRef]

63. Uherek, C.; Tonn, T.; Uherek, B.; Becker, S.; Schnierle, B.; Klingemann, H.G.; Wels, W. Retargeting of natural killer-cell cytolytic activity to ErbB2-expressing cancer cells results in efficient and selective tumor cell destruction. Blood 2002, 100, 1265-1273. [CrossRef] [PubMed]

64. Delconte, R.B.; Kolesnik, T.B.; Dagley, L.F.; Rautela, J.; Shi, W.; Putz, E.M.; Stannard, K.; Zhang, J.-G.; Teh, C.; Firth, M.; et al. CIS is a potent checkpoint in NK cell-mediated tumor immunity. Nat. Immunol. 2016, 17, 816-824. [CrossRef]

65. Riley, R.S.; June, C.H.; Langer, R.; Mitchell, M.J. Delivery technologies for cancer immunotherapy. Nat. Rev. Drug Discov. 2019, 18, 175-196. [CrossRef]

66. Chu, Y.; Yahr, A.; Huang, B.; Ayello, J.; Barth, M.; Cairo, M.S. Romidepsin alone or in combination with anti-CD20 chimeric antigen receptor expanded natural killer cells targeting Burkitt lymphoma in vitro and in immunodeficient mice. OncoImmunology 2017, 6, e1341031. [CrossRef]

67. Mitchell, M.J.; Billingsley, M.M.; Haley, R.M.; Wechsler, M.E.; Peppas, N.A.; Langer, R. Engineering precision nanoparticles for drug delivery. Nat. Rev. Drug Discov. 2020, 20, 101-124. [CrossRef]

68. Billingsley, M.M.; Singh, N.; Ravikumar, P.; Zhang, R.; June, C.H.; Mitchell, M.J. Ionizable Lipid Nanoparticle-Mediated mRNA Delivery for Human CAR T Cell Engineering. Nano Lett. 2020, 20, 1578-1589. [CrossRef] [PubMed] 
69. Kerbauy, L.N.; Marin, N.D.; Kaplan, M.; Banerjee, P.P.; Berrien-Elliott, M.M.; Becker-Hapak, M.; Basar, R.; Foster, M.; Garcia Melo, L.; Neal, C.C.; et al. Combining AFM13, a Bispecific CD30/CD16 Antibody, with Cytokine-Activated Blood and Cord Blood-Derived NK Cells Facilitates CAR-like Responses Against CD30+ Malignancies. Clin. Cancer Res. 2021, 27, $3744-3756$. [CrossRef]

70. Boissel, L.; Betancur, M.; Lu, W.; Krause, D.; Van Etten, R.; Wels, W.; Klingemann, H. Retargeting NK-92 cells by means of CD19and CD20-specific chimeric antigen receptors compares favorably with antibody-dependent cellular cytotoxicity. OncoImmunology 2013, 2, e26527. [CrossRef]

71. Töpfer, K.; Cartellieri, M.; Michen, S.; Wiedemuth, R.; Müller, N.; Lindemann, D.; Bachmann, M.; Füssel, M.; Schackert, G.; Temme, A. DAP12-based activating chimeric antigen receptor for NK cell tumor immunotherapy. J. Immunol. 2015, 194, 3201-3212. [CrossRef]

72. University Health Network, Toronto. A Dose Escalation Study of NK-92 Cell Infusions in Patients with Hematological Malignancies in Relapse After Autologous Stem Cell Transplantation. (Internet). Report No.: NCT00990717. Available online: https: / / clinicaltrials.gov / ct2/show / NCT00990717 (accessed on 7 October 2021).

73. St. Jude Children's Research Hospital. Pilot Study of Genetically Modified Haploidentical Natural Killer Cell Infusions for B-Lineage Acute Lymphoblastic Leukemia (Internet). Report No.: NCT00995137. Available online: https:/ clinicaltrials.gov/ct2 / show / NCT00995137 (accessed on 7 October 2021).

74. Lin, T.P. Pilot Study of Redirected Haploidentical Natural Killer Cell Infusions for B-Lineage Acute Lymphoblastic Leukemia (Internet). Report No.: NCT01974479. Available online: https://clinicaltrials.gov/ct2/show/NCT01974479 (accessed on 7 October 2021).

75. Williams, S.M.; Sumstad, D.; Kadidlo, D.; Curtsinger, J.; Luo, X.; Miller, J.S.; McKenna, D.H., Jr. Clinical-scale production of cGMP compliant CD3/CD19 cell-depleted NK cells in the evolution of NK cell immunotherapy at a single institution. Transfusion 2018, 58, 1458-1467. [CrossRef]

76. Li, H.W.; Vishwasrao, P.; Hölzl, M.A.; Chen, S.; Choi, G.; Zhao, G.; Sykes, M. Impact of Mixed Xenogeneic Porcine Hematopoietic Chimerism on Human NK Cell Recognition in a Humanized Mouse Model. Arab. Archaeol. Epigr. 2016, 17, 353-364. [CrossRef]

77. A Grimm, E.; Robb, R.J.; A Roth, J.; Neckers, L.M.; Lachman, L.B.; Wilson, D.J.; A Rosenberg, S. Lymphokine-activated killer cell phenomenon. III. Evidence that IL-2 is sufficient for direct activation of peripheral blood lymphocytes into lymphokine-activated killer cells. J. Exp. Med. 1983, 158, 1356-1361. [CrossRef]

78. Phillips, J.H.; Lanier, L.L. Dissection of the lymphokine-activated killer phenomenon. Relative contribution of peripheral blood natural killer cells and T lymphocytes to cytolysis. J. Exp. Med. 1986, 164, 814-825. [CrossRef]

79. Mao, Y.; van Hoef, V.; Zhang, X.; Wennerberg, E.; Lorent, J.; Witt, K.; Masvidal, L.; Liang, S.; Murray, S.; Larsson, O.; et al. IL-15 activates mTOR and primes stress-activated gene expression leading to prolonged antitumor capacity of NK cells. Blood 2016, 128, 1475-1489. [CrossRef]

80. Felices, M.; Lenvik, A.J.; McElmurry, R.; Chu, S.; Hinderlie, P.; Bendzick, L.; Geller, M.A.; Tolar, J.; Blazar, B.R.; Miller, J.S. Continuous treatment with IL-15 exhausts human NK cells via a metabolic defect. JCI Insight. 2018, 3. [CrossRef]

81. Romee, R.; Rosario, M.; Berrien-Elliott, M.M.; Wagner, J.A.; Jewell, B.A.; Schappe, T.; Leong, J.W.; Abdel-Latif, S.; Schneider, S.E.; Willey, S.; et al. Cytokine-induced memory-like natural killer cells exhibit enhanced responses against myeloid leukemia. Sci. Transl. Med. 2016, 8, 357ra123. [CrossRef]

82. Müller, T.; Uherek, C.; Maki, G.; Chow, K.U.; Schimpf, A.; Klingemann, H.G.; Tonn, T.; Wels, W.S. Expression of a CD20-specific chimeric antigen receptor enhances cytotoxic activity of NK cells and overcomes NK-resistance of lymphoma and leukemia cells. Cancer Immunol. Immunother. 2008, 57, 411-423. [CrossRef]

83. Esser, R.; Müller, T.; Stefes, D.; Kloess, S.; Seidel, D.; Gillies, S.D.; Aperlo-Iffland, C.; Huston, J.S.; Uherek, C.; Schönfeld, K.; et al. NK cells engineered to express a GD2 -specific antigen receptor display built-in ADCC-like activity against tumour cells of neuroectodermal origin. J. Cell Mol. Med. 2012, 16, 569-581. [CrossRef]

84. Jiang, H.; Zhang, W.; Shang, P.; Zhang, H.; Fu, W.; Ye, F.; Zeng, T.; Huang, H.; Zhang, X.; Sun, W.; et al. Transfection of chimeric anti-CD138 gene enhances natural killer cell activation and killing of multiple myeloma cells. Mol. Oncol. 2014, 8, 297-310. [CrossRef]

85. Sotillo, E.; Barrett, D.M.; Black, K.L.; Bagashev, A.; Oldridge, D.; Wu, G.; Sussman, R.; Lanauze, C.; Ruella, M.; Gazzara, M.R.; et al. Convergence of Acquired Mutations and Alternative Splicing of CD19 Enables Resistance to CART-19 Immunotherapy. Cancer Discov. 2015, 5, 1282-1295. [CrossRef]

86. Spanholtz, J.; Preijers, F.; Tordoir, M.; Trilsbeek, C.; Paardekooper, J.; De Witte, T.; Schaap, N.; Dolstra, H. Clinical-Grade Generation of Active NK Cells from Cord Blood Hematopoietic Progenitor Cells for Immunotherapy Using a Closed-System Culture Process. PLoS ONE 2011, 6, e20740. [CrossRef]

87. Sarvaria, A.; Jawdat, D.; Madrigal, J.A.; Saudemont, A. Umbilical Cord Blood Natural Killer Cells, Their Characteristics, and Potential Clinical Applications. Front. Immunol. 2017, 8, 329. [CrossRef]

88. Kang, L.; Voskinarian-Berse, V.; Law, E.; Reddin, T.; Bhatia, M.; Hariri, A.; Ning, Y.; Dong, D.; Maguire, T.; Yarmush, M.; et al. Characterization and ex vivo Expansion of Human Placenta-Derived Natural Killer Cells for Cancer Immunotherapy. Front. Immunol. 2013, 4, 101. [CrossRef]

89. Bernareggi, D.; Pouyanfard, S.; Kaufman, D.S. Development of innate immune cells from human pluripotent stem cells. Exp. Hematol. 2019, 71, 13-23. [CrossRef] 
90. Karagiannis, P.; Kim, S.I. iPSC-Derived Natural Killer Cells for Cancer Immunotherapy. Mol. Cells 2021, 44, 541-548. [CrossRef]

91. Cichocki, F.; Bjordahl, R.; Gaidarova, S.; Mahmood, S.; Abujarour, R.; Wang, H.; Tuininga, K.; Felices, M.; Davis, Z.B.; Bendzick, L.; et al. iPSC-derived NK cells maintain high cytotoxicity and enhance in vivo tumor control in concert with T cells and anti-PD-1 therapy. Sci. Transl. Med. 2020, 12, eaaz5618. [CrossRef]

92. Hermanson, D.L.; Bendzick, L.; Pribyl, L.; McCullar, V.; Vogel, R.I.; Miller, J.S.; Geller, M.A.; Kaufman, D.S. Induced Pluripotent Stem Cell-Derived Natural Killer Cells for Treatment of Ovarian Cancer. Stem Cells 2015, 34, 93-101. [CrossRef]

93. Saetersmoen, M.L.; Hammer, Q.; Valamehr, B.; Kaufman, D.S.; Malmberg, K.J. Off-the-shelf cell therapy with induced pluripotent stem cell-derived natural killer cells. Semin. Immunopathol. 2019, 41, 59-68. [CrossRef]

94. Fate Therapeutics. FT500 as Monotherapy and in Combination with Immune Checkpoint Inhibitors in Subjects with Advanced Solid Tumors (Phase 1) (Internet). Report No.: NCT03841110. Available online: https://clinicaltrials.gov/ct2/show/NCT03841110 (accessed on 25 November 2021).

95. Fate Therapeutics. A Phase I Study of FT516 as Monotherapy in Relapsed/Refractory Acute Myelogenous Leukemia and in Combination with Monoclonal Antibodies in Relapsed/Refractory B-Cell Lymphoma (Internet). Report No.: NCT04023071. Available online: https:/ / clinicaltrials.gov/ct2/show /NCT04023071 (accessed on 25 November 2021).

96. Wiernik, A.; Foley, B.; Zhang, B.; Verneris, M.R.; Warlick, E.; Gleason, M.K.; Ross, J.A.; Luo, X.; Weisdorf, D.J.; Walcheck, B.; et al. Targeting natural killer cells to acute myeloid leukemia in vitro with a CD16 $\times 33$ bispecific killer cell engager and ADAM17 inhibition. Clin. Cancer Res. 2013, 19, 3844-3855. [CrossRef]

97. Romee, R.; Foley, B.; Lenvik, T.; Wang, Y.; Zhang, B.; Ankarlo, D.; Luo, X.; Cooley, S.; Verneris, M.; Walcheck, B.; et al. NK cell CD16 surface expression and function is regulated by a disintegrin and metalloprotease-17 (ADAM17). Blood 2013, 121, 3599-3608. [CrossRef]

98. Vallera, D.A.; Felices, M.; McElmurry, R.; McCullar, V.; Zhou, X.; Schmohl, J.U.; Zhang, B.; Lenvik, A.J.; Panoskaltsis-Mortari, A.; Verneris, M.R.; et al. IL15 Trispecific Killer Engagers (TriKE) Make Natural Killer Cells Specific to CD33+ Targets While Also Inducing Persistence, In Vivo Expansion, and Enhanced Function. Clin. Cancer Res. 2016, 22, 3440-3450. [CrossRef]

99. Eyquem, J.; Mansilla-Soto, J.; Giavridis, T.; van der Stegen, S.J.C.; Hamieh, M.; Cunanan, K.M.; Odak, A.; Gönen, M.; Sadelain, M. Targeting a CAR to the TRAC locus with CRISPR/Cas9 Enhances Tumour Rejection. Nature 2017, 543, 113-117. Available online: https: / / www.nature.com/articles / nature21405 (accessed on 27 November 2021). [CrossRef]

100. Han, J.; Chu, J.; Chan, W.K.; Zhang, J.; Wang, Y.; Cohen, J.; Victor, A.; Meisen, W.H.; Kim, S.-H.; Grandi, P.; et al. CAR-Engineered NK Cells Targeting Wild-Type EGFR and EGFRvIII Enhance Killing of Glioblastoma and Patient-Derived Glioblastoma Stem Cells. Sci. Rep. 2015, 5, 11483. [CrossRef] [PubMed]

101. Felices, M.; Lenvik, T.R.; Davis, Z.B.; Miller, J.S.; Daniel, A.; Vallera, D.A. Generation of BiKEs and TriKEs to improve NK cell-mediated targeting of tumor cells. Methods Mol. Biol. 2016, 1441, 333-346. [PubMed]

102. Zhao, X.; Rajasekaran, N.; Reusch, U.; Marschner, J.P.; Treder, M.; Kohrt, H. CD30/CD16A Tandab AFM13-Induced Target Cell Lysis By NK-Cells Is Enhanced by CD137 Co-Stimulation and Blocking PD-1. Blood 2015, 126, 2747. [CrossRef]

103. Cho, M.M.; Quamine, A.E.; Olsen, M.R.; Capitini, C.M. Programmed cell death protein 1 on natural killer cells: Fact or fiction? J. Clin. Investig. 2020, 130, 2816-2819. [CrossRef]

104. Sahm, C.; Schönfeld, K.; Wels, W.S. Expression of IL-15 in NK cells results in rapid enrichment and selective cytotoxicity of gene-modified effectors that carry a tumor-specific antigen receptor. Cancer Immunol. Immunother. 2012, 61, 1451-1461. [CrossRef] [PubMed]

105. Tassev, D.V.; Cheng, M.; Cheung, N.K. Retargeting NK92 cells using an HLA-A2-restricted, EBNA3C-specific chimeric antigen receptor. Cancer Gene Ther. 2012, 19, 84-100. [CrossRef] [PubMed]

106. Zhang, G.; Liu, R.; Zhu, X.; Wang, L.; Ma, J.; Han, H.; Wang, X.; Zhang, G.; He, W.; Wang, W.; et al. Retargeting NK-92 for anti-melanoma activity by a TCR-like single-domain antibody. Immunol. Cell Biol. 2013, 91, 615-624. [CrossRef] [PubMed]

107. Schönfeld, K.; Sahm, C.; Zhang, C.; Naundorf, S.; Brendel, C.; Odendahl, M.; Nowakowska, P.; Bönig, H.; Köhl, U.; Kloess, S.; et al. Selective inhibition of tumor growth by clonal NK cells expressing an ErbB2/HER2-specific chimeric antigen receptor. Mol. Ther. 2015, 23, 330-338. [CrossRef] [PubMed]

108. Chu, J.; Deng, Y.; Benson, D.M.; He, S.; Hughes, T.P.; Zhang, J.; Peng, Y.; Mao, H.; Yi, L.; Ghoshal, K.; et al. CS1-specific chimeric antigen receptor (CAR)-engineered natural killer cells enhance in vitro and in vivo antitumor activity against human multiple myeloma. Leukemia 2013, 28, 917-927. [CrossRef] [PubMed] 